\title{
KESIAPAN PSIKOLOGIS MASYARAKAT PEDESAAN DAN PERKOTAAN MENGHADAPI DIVERSIFIKASI PANGAN POKOK
}

\author{
Nurul Hidayah \\ Fakultas Psikologi \\ Universitas Ahmad Dahlan \\ Jalan Kapas No. 9 Yogyakarta \\ nurul_psi_uad@yahoo.co.id
}

\begin{abstract}
The purpose of this research was exploring psychological readiness toward the diversification of primary food among rural and urban community. The subjects were the residences at Kecamatan Gedang Sari Kabupaten Gunungkidul and the residences at Kecamatan Gedongtengen Kota Yogyakarta. Data were obtained through questionnaire tools, observation and interview. Analysis was done by qualitative analysis and descriptive statistics. The result of this research indicated that: (1) the rate of knowledge about the diversification of primary food among urban people was higher than rural people; (2) rural and urban people have the same positive attitude to the diversification of primary food; (3) rural people have applied the diversification of primary food, but they still have extrinsic motivation; (4) urban people haven't been ready yet to apply the diversification of primary food; (5) there was the difference of primary food variance among rural and urban community; cassava was the rural people's choice and wheat was the urban people's choice.
\end{abstract}

Keywords: Food Diversification, Psychological Readiness, Rural and Urban Community.

\begin{abstract}
Abstrak
Penelitian ini bertujuan untuk menjajagi kesiapan masyarakat pedesaan dan perkotaan terhadap program diversifikasi pangan pokok. Subjek penelitian adalah masyarakat Kecamatan Gedang Sari Kabupaten Gunungkidul dan masyarakat Kecamatan Gedongtengen Kota Yogyakarta. Data diperoleh dari hasil pengisian angket, observasi dan wawancara.
\end{abstract}


Analisis dilakukan menggunakan analisis kualitatif dan statistik deskriptif. Hasil penelitian menunjukkan bahwa: (1) tingkat pengetahuan yang dimiliki tentang diversifikasi pangan pokok pada masyarakat perkotaan lebih tinggi daripada masyarakat pedesaan; (2) masyarakat perkotaan dan pedesaan sama-sama memiliki sikap positif terhadap diversifikasi pangan pokok; (3) masyarakat pedesaan sudah menerapkan diversifikasi pangan pokok, namun motivasinya masih bersifat ekstrinsik. (4) masyarakat perkotaan belum siap menerapkan diversifikasi pangan pokok secara total; (5) terdapat perbedaan jenis pangan pokok non beras yang dipilih antara masyarakat pedesaan dan masyarakat perkotaan; masyarakat pedesaan memilih ketela (umbi-umbian) sedangkan masyarakat perkotaan memilih makanan olahan berbasis gandum.

Kata kunci: Diversifikasi Pangan, Kesiapan Psikologis, Masyarakat Pedesaan dan Perkotaan.

\section{Pendahuluan}

Makanan pokok (pangan pokok) merupakan salah satu kebutuhan primer manusia. Banyak varian makanan pokok yang dapat dikonsumsi manusia. Tiap daerah memiliki makanan pokok sendiri-sendiri. Penentuan jenis pangan yang dikonsumsi sangat tergantung pada beberapa faktor, di antaranya jenis tanaman penghasil bahan makanan pokok yang biasa ditanam di daerah tersebut serta tradisi yang diwariskan oleh budaya setempat. Perilaku konsumsi pangan masyarakat dilandasi oleh kebiasaan makan (food habit) yang tumbuh dan berkembang dalam lingkungan keluarga melalui proses sosialisasi. Kebiasaan makan tersebut dapat dipengaruhi oleh lingkungan ekologi (ciri tanaman pangan, ternak dan ikan yang tersedia dan dapat dibudidayakan setempat), lingkungan budaya dan sistem ekonomi .

Saat ini konsumsi beras di Indonesia sebesar 139,15 kg/kapita/tahun. Angka ini cukup tinggi dan berada di atas rata-rata konsumsi beras dunia sebesar $60 \mathrm{~kg} /$ kapita/tahun. Adapun konsumsi terigu telah mencapai 10,32 kg/kapita/tahun. Hal ini menunjukkan keragaman pola konsumsi pangan masyarakat belum terwujud, dan konsumsi masyarakat masih didominasi oleh kelompok padi-padian. Perkembangan konsumsi penduduk Indonesia terhadap umbi-umbian memang berjalan sangat lambat sehingga harus ada upaya terpadu agar mendekati angka ideal. Badan Pusat Statistik (BPS) mencatat, konsumsi padi-padian tiap rumah tangga pada tahun 2009 sebanyak 314,4 gram, sedangkan umbi-umbian hanya 48 gram. Padahal idealnya, untuk padipadian konsumsinya sebanyak 27,8 gram dan umbi-umbian 100 gram 
(www.bataviase.co.id/node/390688, diakses tanggal 21 September 2011). Pemerintah sebaiknya mulai menjadikan produk pertanian tak lagi sebagai produk generik. Oleh karena itu kesadaran konsumsi terhadap pangan lokal harus ditingkatkan. Peningkatan kesadaran tersebut dilakukan supaya permintaan komoditi pangan lokal berkembang, yang dimulai dari tingkat rumah tangga hingga tingkat nasional. Produk lokal seperti beras cianjur, beras pandanwangi, tiwul dan gatot, semestinya dapat dikelola menjadi produk unggulan dengan nilai jual tinggi. Pemerintah juga perlu mereformasi strategi portofolio pangan rakyat, terutama karbohidrat yang sangat berfokus pada beras.

PP Ketahanan Pangan No. 68 tahun 2002 pasal 9 ayat 2 disebutkan bahwa salah satu cara penganekaragaman pangan adalah dengan meningkatkan kesadaran masyarakat untuk mengkonsumsi aneka ragam pangan dengan prinsip gizi seimbang. Oleh karena itu sangat penting melakukan kampanye atau sosialisasi pentingnya penganekaragaman pangan non beras. Aturan formal (tertulis) sudah ada, seperti Undang-undang Nomor 7 Tahun 1996 tentang Pangan, Peraturan Pemerintah mengenai Ketahanan Pangan (PP No. 68 tahun 2002) dan Pedoman Umum Penganekaragaman Pangan yang telah disusun. Memang upaya kampanye sudah mulai dilakukan, misalnya melalui pemerintah daerah setempat, media massa, internet, dan sebagainya, tetapi diasumsikan bahwa belum semua kelompok masyarakat sudah memahami kampanye tersebut dan siap melakukan diversifikasi pangan .

Agar sosialisasi tersebut dapat mencapai sasaran, perlu dilakukan penjajagan awal mengenai kesiapan masyarakat untuk menerima diversifikasi pangan pokok dan selanjutnya menjadikan pangan non beras sebagai bagian dari food habit. Kesiapan di sini meliputi pengetahuan yang dimiliki dan sikap terhadap diversifikasi pangan pokok, serta kecenderungan untuk mengkonsumsi pangan pokok non beras. Beras sudah "melekat di hati" masyarakat. Beras memang memiliki kelebihankelebihan, antara lain mudah dimasak (praktis), bahkan kini masyarakat semakin dimanjakan dengan ditawarkannya alat menanak nasi modern nan praktis, seperti rice cooker dan magic com. Selain itu memasak nasi tidak harus menyertakan bahan makanan lain, lagi pula rasanya netral sehingga cocok untuk dipadupadankan dengan semua jenis lauk pauk dan tidak membosankan. Berdasarkan hasil wawancara dengan sejumlah penduduk baik di wilayah pedesaan maupun perkotaan, sebagian besar masyarakat nampaknya masih sulit untuk meninggalkan beras sebagai makanan pokok. Seseorang belum dianggap makan kalau belum makan nasi, meskipun sudah menyantap mie instan atau roti tawar. Kalaupun ada yang menganggap bahwa makan roti merupakan pengganti sarapan, mereka belum bersedia melewatkan hari tanpa makan nasi sama sekali. Kebiasaan seperti ini akan menghambat penyesuaian diri, terlebih apabila ada yang harus bepergian keluar negeri yang di negara tujuan tersebut 
tidak tersedia beras.

Masalah berikutnya adalah: samakah tingkat kesiapan masyarakat pedesaan dan perkotaan dalam menyikapi diversifikasi pangan. Diasumsikan bahwa kebiasaan makan tersebut dapat dipengaruhi oleh faktor budaya. Masyarakat pedesaan dan perkotaan memiliki sistem budaya dan gaya hidup yang berbeda, sehingga dimungkinkan bahwa kecenderungan untuk mengkonsumsi makanan pokok non beras yang saat ini mulai disosialisasikan akan berbeda. Apakah masyarakat pedesaan siap mengkonsumsi gandum yang dari segi harga dan kontinuitas ketersediaan merupakan alternatif pengganti beras? Masih ada anggapan bahwa harga produk olahan gandum seperti roti relatif mahal. Sebaliknya, apakah masyarakat perkotaaan siap mengkonsumsi produk lokal seperti gaplek, jagung, dan sagu sebagai pengganti beras, yang dianggap tidak modern? Berdasarkan permasalahan di atas penulis tertarik untuk meneliti lebih lanjut kesiapan psikologis masyarakat dalam menghadapi diversifikasi pangan pokok nasional.

Diversifikasi atau penganekaragaman pangan adalah proses pemilihan pangan yang tidak tergantung kepada satu jenis saja, melainkan terhadap macam-macam bahan pangan mulai dari aspek produksi, aspek pengolahan, aspek distribusi hingga aspek konsumsi pangan tingkat rumah tangga (www.iptek.apjii.or.id., 25 Desember 2006). Penganekaragaman pangan adalah upaya peningkatan konsumsi aneka ragam pangan dengan prinsip gizi seimbang. Penganekaragaman dapat dilakukan dengan cara: (1) meningkatkan keanekaragaman pangan, (2) mengembangkan teknologi pengolahan dan produk pangan, dan (3) meningkatkan kesadaran masyarakat untuk mengkonsumsi aneka ragam pangan dengan prinsip gizi seimbang (www.iptek.apjii. or.id., 25 Desember 2006). Diversifikasi pangan dilakukan dengan tujuan untuk meningkatkan ketahanan pangan dengan memperhatikan sumber daya, kelembagaan dan budaya lokal. Menurut PP No. 68 tahun 2002, ketahanan pangan merupakan kondisi terpenuhinya pangan bagi rumah tangga yang tercermin dari ketersediaan pangan yang cukup, baik jumlah maupun mutunya, aman, merata, dan terjangkau.

Ketahanan pangan merupakan hal yang penting dan strategis, karena berdasarkan pengalaman di banyak negara menunjukkan bahwa tidak ada satu negarapun yang dapat melaksanakan pembangunan secara mantap sebelum mampu mewujudkan ketahanan pangan terlebih dahulu. Undang-undang Nomor 7 Tahun 1996 tentang Pangan mengamanatkan bahwa pemerintah bersama masyarakat mewujudkan ketahanan pangan bagi seluruh rakyat Indonesia. Selanjutnya, dalam PP No. 68 tahun 2002 dijelaskan bahwa karena Indonesia merupakan negara dengan jumlah penduduk yang banyak dan tingkat pertumbuhannya yang tinggi, maka upaya untuk mewujudkan ketahanan pangan merupakan tantangan yang harus mendapatkan 
prioritas untuk kesejahteraan bangsa. Indonesia sebagai negara agraris dan maritim dengan sumber daya alam dan sosial budaya yang beragam, harus dipandang sebagai karunia Ilahi untuk mewujudkan ketahanan pangan. Upaya mewujudkan ketahanan pangan nasional harus bertumpu pada sumberdaya pangan lokal yang mengandung keragaman antar daerah dan harus dihindari sejauh mungkin ketergantungan pada pemasukan pangan.

Kesiapan psikologis meliputi pengetahuan, sikap dan kecenderungan untuk melakukan tindakan tertentu. Diterapkan pada program diversifikasi pangan, kesiapan psikologis meliputi pengetahuan tentang diversifikasi pangan, sikap terhadap diversifikasi pangan, kecenderungan untuk mengkonsumsi pangan pokok non beras dan jenis pangan pokok non beras yang ingin dikonsumsi. Menurut Angel dkk (1992) pengetahuan didefinisikan sebagai informasi yang disimpan dalamingatan. Pengetahuan konsumen diartikan sebagai himpunan bagian dari informasi total yang relevan dengan fungsi konsumen di dalam pasar. Informasi yang dipegang oleh masyarakat mengenai produk yang akan dikonsumsi akan sangat mempengaruhi pola pembelian mereka. Allport (Sears dkk, 1985) mengemukakan bahwa sikap adalah keadaan mental dari kesiapan, yang diatur melalui pengalaman yang memberikan pengaruh dinamik atau terarah terhadap respon individu pada semua objek dan situasi yang berkaitan dengannya. Berkowitz (Azwar, 1988) mendefinisikan sikap sebagai suatu bentuk evaluasi atau perasaan seseorang terhadap suatu obyek, yaitu perasaan mendukung atau memihak (favorable) maupun perasaan tidak mendukung (unfavorable) pada objek tersebut. Newcomb (Azwar, 1988) mendefinisikan sikap sebagai organisasi keadaan psikologik yang meliputi motivasi, persepsi, pikiran dan perasaan yang berhubungan dengan sesuatu yang dianggap penting oleh seseorang dan mempunyai asosiasi positif dan negatif.

Thurstone (Suryabrata, 2003) mengatakan bahwa sikap merupakan suatu tindakan afek atau rasa mendalam yang bersifat positif atau negatif dan berhubungan dengan obyek tertentu disertai perasaan senang atau tidak senang, simpati atau antipati. Sikap bukanlah tindakan tetapi merupakan kesiapan untuk bertindak. Secord dan Bucman (Azwar, 1988) berpendapat bahwa sikap merupakan triadic scheme yaitu sebagai keteraturan tertentu dalam hal perasaan (afeksi), pemikiran (kognisi), dan predisposisi tindakan (konasi) seseorang terhadap suatu aspek. Jadi sikap memiliki tiga komponen yang saling menunjang, yaitu komponen kognitif, komponen afektif dan komponen konatif. Komponen kognitif berupa apa yang dipercayaioleh subjek pemilik sikap. Komponen afektif merupakan komponen perasaan yang menyangkut aspek emosional. Komponen konatif merupakan aspek kecenderungan berperilaku (intensi) tertentu sesuai dengan sikap yang dimiliki oleh subjek, yaitu kemungkinan yang disadari bahwa perilaku tertentu akan terjadi. Dengan demikian dapat disimpulkan bahwa 
sikap adalah evaluasi yang dilakukan oleh seseorang terhadap suatu obyek, meliputi aspek kognitif, afektif dan konatif, dapat bersifat positif atau negatif.

Berkaitan dengan aspek psikologi pemilihan bahan pangan, Gibney dkk (2005) menjelaskan bahwa studi pemilihan makanan pada manusia melibatkan banyak interaksi kompleks yang mencakup berbagai bidang, mulai dari mekanisme biologis pengendalian selera makan, psikologi perilaku makan, nilai-nilai sosial dan budaya, hingga berbagai upaya kesehatan masyarakat dan komersial untuk mengubah asupan makanan pada populasi tertentu. Pemilihan makanan tampak jelas sebagai hasil akhir suatu proses pengambilan keputusan sebagai tujuan maupun sebagai suatu mekanisme atau proses. Berdasarkan tinjauan psikologi perilaku makan, ada beberapa atribut personal yang mempengaruhi individu dalam memilih bahan pangan, antara lain persepsi terhadap atribut sensorik (misalnya cita rasa dan tekstur), faktor psikologi (misalnya faktor emosi seperti mood dan faktor sikap) dan lingkungan sosial (misalnya norma budaya, pengiklanan, faktor ekonomi, dan ketersediaan produk pangan). Pemahaman proses pemilihan makanan di tingkat individu bersifat kompleks. Pengalaman dalam perjalanan hidup individu akan mempengaruhi faktor-faktor utama yang berpengaruh terhadap proses pemilihan makanan. Faktor tersebut mencakup idealisme, faktor personal, sumber daya, konteks sosial dan konteks makanan. Selanjutnya pengaruh tersebut menginformasikan pengembangan berbagai sistem personal untuk memilih makanan menggunakan negosiasi nilai-nilai dan strategi perilaku. Model perilaku memilih makanan berdasarkan atribut personal dapat dilihat pada gambar 1.

Pola konsumsi pangan adalah susunan makanan yang mencakup jenis dan jumlah bahan makanan rata-rata per orang per hari yang umum dikonsumsi atau dimakan penduduk dalam jangka waktu tertentu. Salah satu faktor yang mempengaruhi pola konsumsi pangan adalah kebiasaan atau gaya hidup (www.iptek.apjii.or.id., 25 Desember 2006). Gaya hidup didefinisikan sebagai pola tempat orang hidup dan menghabiskan waktu serta uang yang dimiliki. Gaya hidup adalah fungsi motivasi konsumen dan pembelajaran sebelumnya, ekonomi, budaya, kelas sosial, demografi, dan variabel lain. Gaya hidup adalah konsepsi ringkasan yang mencerminkan nilai konsumen. Gaya hidup merupakan variabel yang bersifat dinamis dan relatif mudah untuk berubah lebih cepat (Angel dkk, 1992). Lebih jauh, Angel dkk (1992) menjelaskan bahwa psikografi merupakan teknik utama yang digunakan oleh peneliti untuk mendefinisikan gaya hidup secara operasional. Tiga aspek yang diukur disingkat dengan AIO, A adalah activity (aktivitas), I adalah interest (minat) dan $\mathrm{O}$ adalah opinions (opini). Salah satu faktor yang mempengaruhi gaya hidup adalah variabel demografi, sehingga secara tidak langsung variabel demografi merupakan salah satu faktor yang berpengaruh terhadap keputusan untuk mengkonsumsi makanan pokok. Tempat tinggal (desa dan kota) merupakan salah satu variabel demografi. 


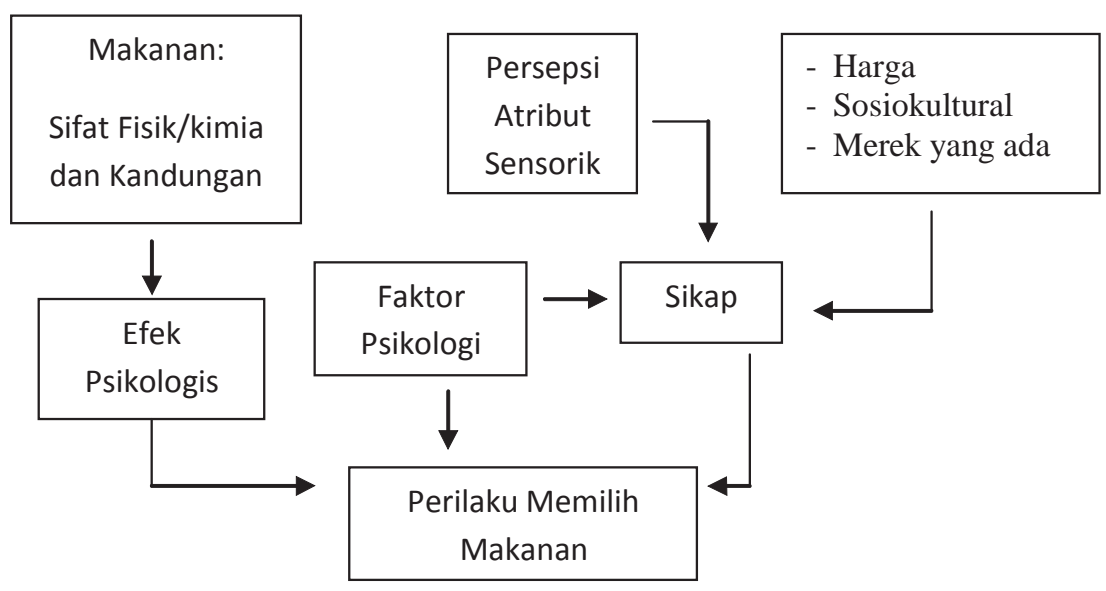

Gambar 1.

Model Perilaku Memilih Makanan (Shepred, dalam Gibney, dkk, 2005).

Masyarakat merupakan kumpulan dari individu-individu baik dalam kelompok kecil maupun besar yang memiliki pengaruh satu sama lain sehingga memiliki kebiasaan tradisi, sikap kebatinan dan persatuan dalam kesatuan sosial. Dalam masyarakat modern, sering dibedakan antara masyarakat pedesaan (rural community) dan masyarakat perkotaan (urban community). Menurut Soekanto (1998), perbedaan tersebut sebenarnya tidak mempunyai hubungan dengan pengertian masyarakat sederhana, karena dalam masyarakat modern, betapa pun kecilnya suatu desa, pasti ada pengaruh-pengaruh dari kota. Perbedaan masyarakat pedesaan dan masyarakat perkotaan, pada hakekatnya bersifat gradual. Menurut Bauman (1996) desa adalah salah satu bentuk kuno dari kehidupan bersama, sebanyak-banyaknya beberapa ribu orang yang hampir semuanya saling mengenal. Mata pencaharian utama penduduk pedesaan adalah bertani, berternak, perikanan, buruh serta usaha-usaha yang sangat dipengaruhi hukum alam. Menurut Soekanto (1998) ciri-ciri menonjol pada masyarakat pedesaan adalah: (1) kehidupan masyarakatnya agamis; (2) pembagian kerja tidak nyata, dan (3) jalan pemikiran orang desa lebih bersifat sosial dibandingkan orang kota yang lebih bersifat ekonomis dan rasional.

Adapun kota menurut Suparlan (1995) merupakan pusat kegiatan kebudayaan yang jaringannya meliputi satuan-satuan administrasi, politik, ekonomi dan komunikasi. Kota dikenal juga sebagai pusat pemerintahan, kebudayaan, perdagangan serta perindustrian. Menurut Soekanto (1998) penduduk kota padat dan tingkat heterogenitasnya tinggi. Beberapa ciri masyarakat perkotaan adalah: (1) tingkat religiusitasnya kurang dibandingkan masyarakat pedesaan, (2) individualitasnya lebih tinggi, (3) pembagian kerja antar warga lebih tegas dan memiliki batas-batas tegas, 
(4) jalan pikiran rasional, dan (5) perubahan-perubahan sosial tampak nyata karena masyarakat kota lebih terbuka menerima pengaruh luar.

Perbedaan gaya hidup masyarakat pedesaan dan perkotaan yang akan mempengaruhi perbedaan dalam pola konsumsi, dapat dilihat pada tabel 1.

Berdasarkan telaah pustaka di atas, dapat disimpulkan bahwa kesiapan psikologis masyarakat dalam menghadapi diversifikasi pangan pokok adalah tingkat pengetahuan yang dimiliki masyarakat mengenai diversifikasi pangan pokok dan sikap masyarakat, yang meliputiaspek kognitif, afektif dan konatif terhadap obyek sikap berupa diversifikasi pangan pokok, sebagai predisposisi (prediktor) dilaksanakannya diversifikasi pangan pokok dalamkehidupan sehari-hari. Pengetahuan tentang diversifikasi pangan pokok meliputi pengetahuan tentang pengertian diversifikasi pangan pokok, manfaat diversifikasi pangan pokok dan cara melaksanakan kegiatan diversifikasi pangan pokok. Sikap terhadap diversifikasi pangan pokok adalah sejauh mana kepercayaan masyarakat tentang pentingnya diversifikasipangan pokok, rasa senang atau tidak senang terhadap diversifikasi pangan pokok dan kecenderungan untuk melaksanakan diversifikasi pangan pokok. Sosiokultural merupakan salah satu faktor yang mempengaruhi perilaku pemilihan makanan, sehingga budaya perkotaan dan pedesaan yang berbeda dapat mempengaruhi keputusan melakukan diversifikasi pangan.

\section{Metode Penelitian}

Variabel penelitian ini berupa kesiapan psikologis menghadapi diversifikasi pangan pokok. Kesiapan psikologis terdiri tiga komponen. Komponen pertama adalah pengetahuan tentang diversifikasi pangan pokok, komponen kedua adalah sikap terhadap diversifikasi pangan pokok, dan komponen ketiga adalah kecenderungan untuk mengkonsumsi pangan pokok non beras.

Subjek penelitian ini terdiri dua kelompok. Kelompok pertama mewakili masyarakat pedesaan, dipilih penduduk di wilayah Kecamatan Gedang Sari Kabupaten Gunungkidul. Kelompok kedua mewakili masyarakat perkotaan dipilih penduduk di wilayah Kecamatan Gedongtengen Kota Yogyakarta. Kedua wilayah ini masih berada dalam satu propinsi yaitu Daerah Istimewa Yogyakarta. Dipilihnya lokasi yang masih dalam satu propinsi ini dengan pertimbangan, antara lain sumber daya alam yang masih sama, hal ini dikaitkan dengan bahan pangan pokok yang dihasilkan dan memungkinkan dikonsumsi oleh masyarakat.

Metode penelitian ini menggunakan pendekatan kualitatif yaitu observasi dan wawancara semi terstruktur. Panduan wawancara sudah dibuat secara garis besar 


\section{Tabel 1.}

Perbandingan Masyarakat Pedesaan dan Perkotaan

\begin{tabular}{|c|c|c|c|}
\hline No & Aspek & Pedesaan & Perkotaan \\
\hline 1. & Lingkungan fisik & $\begin{array}{l}\text { Didominasi pepohonan, } \\
\text { udara masih segar. } \\
\text { Fasilitas fisik kurang } \\
\text { lengkap. Pemukiman } \\
\text { tidak padat. }\end{array}$ & $\begin{array}{l}\text { Didominasi bangunan buatan, } \\
\text { udara berpolusi. Fasilitas fisik } \\
\text { lebih lengkap. Pemukiman padat } \\
\text { dan sesak. }\end{array}$ \\
\hline 2. & $\begin{array}{l}\text { Lingkungan } \\
\text { Sosial }\end{array}$ & $\begin{array}{l}\text { Kepadatan penduduk rendah, } \\
\text { lapangan kerja didominasi } \\
\text { sektor pertanian. Tingkat } \\
\text { pendidikan lebih rendah. } \\
\text { Tingkat perekonomian dan } \\
\text { gaya hidup relatif homogen. } \\
\text { Relasi sosial kuat. }\end{array}$ & $\begin{array}{l}\text { Kepadatan penduduk tinggi, } \\
\text { lapangan kerja didominasi sektor } \\
\text { industri. Tingkat pendidikan lebih } \\
\text { tinggi. Tingkat perekonomian dan } \\
\text { gaya hidup heterogen. Relasi } \\
\text { sosial melemah. }\end{array}$ \\
\hline 3. & Nilai hidup & $\begin{array}{l}\text { Berjuang untuk bertahan } \\
\text { hidup. Dapat makan } \\
\text { teratur sudah lumayan. }\end{array}$ & $\begin{array}{l}\text { Lebih memperhatikan kesehatan, } \\
\text { keamanan dan prestise. } \\
\text { Jangankan makanan pokok, } \\
\text { barang-barang mewah saja } \\
\text { mampu dibeli. }\end{array}$ \\
\hline 4. & $\begin{array}{l}\text { Kecenderungan } \\
\text { pangan pokok } \\
\text { yang dikonsumsi }\end{array}$ & $\begin{array}{l}\text { Sebisa mungkin tidak } \\
\text { usah membeli; kalaupun } \\
\text { membeli yang terjangkau } \\
\text { oleh kantong. }\end{array}$ & $\begin{array}{l}\text { Makanan yang praktis (cara } \\
\text { memasak maupun menyantap) } \\
\text { dan enak, harga bukan } \\
\text { pertimbangan utama. }\end{array}$ \\
\hline 5. & $\begin{array}{l}\text { Kecenderungan } \\
\text { diversifikasi } \\
\text { makanan pokok }\end{array}$ & $\begin{array}{l}\text { Relatif sering melakukan } \\
\text { diversifikasi, namun motivasi } \\
\text { untuk melakukan diversifikasi } \\
\text { bersifat ekstrinsik (keadaan } \\
\text { darurat, harga beras tidak } \\
\text { terjangkau). }\end{array}$ & $\begin{array}{l}\text { Masih belum siap. Diversifikasi } \\
\text { pangan hanya sebagai pangan } \\
\text { selingan atau saat makan pagi. } \\
\text { Seandainya siap, motivasinya } \\
\text { lebih bagus karena bersifat } \\
\text { intrinsik. }\end{array}$ \\
\hline
\end{tabular}

(Suparlan, 1995; Angel dkk, 1992; dan Sarwono, 1992)

dan dapat dikembangkan sendiri oleh pewawancara sesuai dengan situasi dan kondisi di lapangan. Pengumpulan data juga menggunakan pendekatan kualitatif. Adapun metode kualitatif dimaksud adalah PRA (Participatory Rural Appraisal) yaitu suatu metode TECESIBERA(Telaah Cepat Bersama Rakyat). PRAadalah sekumpulan pendekatan dan metode yang mendorong masyarakat pedesaan untuk turut serta meningkatkan dan menganalisis pengetahuan mereka mengenai hidup dan kondisi mereka sendiri, agar mereka dapat membuat rencana dan tindakan. Metode ini dapat juga diterapkan pada masyarakat perkotaan (LPIST-YASIN, 1992).

Kelebihan dari metode PRA antara lain: membutuhkan waktu yang tidak terlalu 
lama, cakupannya luas, teknik yang beraneka ragam dengan alat utama wawancara semi terstruktur, analisis statistik sedikit sekali, analisis kualitatif sangat penting, dan partisipasi masyarakat tinggi. Pelaksanaan kajian dengan teknik-teknik PRA bisa dilakukan perorangan (misalnya oleh petugas lapangan dalam menjalankan kegiatannya), maupun secara khusus oleh sebuah tim yang terdiri dari sejumlah orang yang keanggotaannya mempunyai keseragaman latar belakang baik dari segi pendidikan, pengalaman maupun keterampilannya. Prinsip-prinsip dasar dari PRA yaitu: (1) mengutamakan yang terbaik, (2) pemberdayaan masyarakat, (3) masyarakat sebagai pelaku, orang luar sebagai fasilitator, (4) saling belajar dan menghargai perbedaan, (5) santai dan informal, (6) Chek dan Re-Chek informasi, (7) mengoptimalkan hasil, (8) orientasi praktis, (9) keberlanjutan dan selang waktu, (10) belajar dari kesalahan, dan (11) tertulis. Teknik-teknik yang akan digunakan dalam penelitian ini meliputi observasi, wawancara semi terstruktur, dan pengumpulan data sekunder.

Sumber data yang digunakan dalam penelitian ini adalah sumber data primer yaitu sumber data penelitian yang diperoleh secara langsung dari sumber asli, tanpa melalui media perantara. Sumber data primer dalam penelitian ini adalah pada jenis data subyek (self-report data). Data hasil penelitian dianalisis secara kualitatif sehingga diperoleh deskripsi dan kesimpulan yang dapat menjawab pertanyaan-pertanyaan penelitian.

\section{Hasil dan Pembahasan}

Berdasarkan data demografik kelompok usia dengan frekuensi terbanyak adalah kelompok usia 20-30 tahun pada subjek perkotaan, sedangkan subjek pedesaan didominasi kelompok usia 30-50 tahun. Kelompok remaja terwakili pada subjek perkotaan, sedangkan kelompok lansia terwakili pada kedua-duanya. Perbedaan yang tampak menyolok adalah dari segi pendidikan dan pekerjaan. Pada kelompok subjek perkotaan, tingkat pendidikan bervariasi mulai dari SD hingga perguruan tinggi (S2), namun didominasi oleh lulusan SLTA dan hanya sebagian kecil yang merupakan lulusan SD maupun bergelar magister. Adapun pada kelompok subjek pedesaan, masih ada subjek yang tidak bersekolah atau tidak lulus SD. Mayoritas subjek adalah lulusan SD dan hanya sebagian kecil yang merupakan lulusan sekolah menengah (SLTP dan SLTA) dengan SLTA sebagai tingkat pendidikan tertinggi.

Pada kelompok subjek perkotaan, jenis pekerjaan subjek penelitian sangat variatif dan didominasi oleh profesi wiraswasta. Kelompok subjek yang tidak bekerja 
atau sebagai ibu rumah tangga juga cukup banyak, namun tidak ada yang berprofesi sebagai petani. Adapun pada kelompok subjek pedesaan, sebagian besar subjek bekerja sebagai petani di ladang dan sebagai buruh, dan hanya sebagian kecil yang bekerja sebagai PNS atau berwiraswasta. Merujuk pada hasil riset terdahulu berupa riset kesehatan di Skotlandia (Gibney dkk, 2005) menunjukkan bahwa pemilihan makanan terpola secara sosial menurut variabel demografik yang penting, yaitu usia, jenis kelamin, kelas sosial, etnis, dan status perkawinan.

Berdasarkan hasil penelitian terdapat perbedaan kesiapan psikologis antara masyarakat pedesaan dan perkotaan menghadapi diversifikasi pangan pokok. Ditinjau dari segi sikap, sebetulnya masyarakat desa dan kota sama-sama mendukung program diversifikasi pangan ini. Adapun ditinjau dari segi pengetahuan tentang diversifikasi pangan, masyarakat kota memiliki tingkat pengetahuan yang lebih tinggi. Hal ini kemungkinan dipengaruhi oleh latar belakang pendidikan penduduk perkotaaan yang relatif lebih tinggi sehingga mempengaruhi wawasan mereka tentang pentingnya menjaga ketahanan pangan negara melalui diversifikasi pangan. Hanya apabila betulbetul diterapkan, masyarakat perkotaan merasa belum siap menerapkannya. Masyarakat pedesaan sebetulnya sudah lama menerapkan diversifikasi ini, namun wawasan mereka tentang pentingnya diversifikasi ini cukup minim, kemungkinan karena tingkat pendidikan yang rendah. Penerapan diversifikasi ini dilakukan oleh masyarakat desa karena keterpaksaan, misalnya karena harga beras yang sulit terjangkau akibat tingkat perekonomian yang rendah. Ketela atau singkong merupakan pilihan pangan karena kebanyakan dari mereka menanam sendiri ketela tersebut. Ketela adalah tanaman yang mudah ditanam, tidak membutuhkan perawatan intensif dan dapat ditanam di lahan kering sehingga sesuai dengan kondisi tanah di lokasi penelitian yang berbukit-bukit dan kering. Bagi yang tidak memiliki lahan sendiri, mereka dapat membeli ketela dengan harga terjangkau. Ketela dan jagung dikonsumsi berselang-seling dengan beras karena padi hanya ditanam pada musim penghujan (sawah tadah hujan) sehingga mereka tidak dapat mengandalkan pangan pokok dari beras saja.

Akses terhadap produk pangan juga mempengaruhi perilaku pemilihan pangan (Cox dan Anderson, dalam Gibney dkk, 2005). Konsep ketersediaan pangan terentang mulai dari penjualan eceran (retailing) setempat hingga ketersediaannya di lingkungan rumah. Selama ini pangan berbasis beras tersedia cukup merata di wilayah Indonesia, artinya apabila masyarakat memiliki daya beli yang baik maka mereka mampu mengkonsumsi nasi karena pemerintah ikut membantu akses terhadap produk beras dengan berbagai cara. Adapun diversifikasi terhadap ketela atau singkong pada 
masyarakat pedesaan lebih didasarkan pada kemudahan akses terhadap produk ketela tersebut, baik diperoleh dari hasil penanaman sendiri maupun membeli di pasar setempat. Adapun peluang untuk meningkatkan produksi ketela atau singkong dalam skala besar sehingga dapat didistribusikan ke wilayah yang lebih luas masih terhambat oleh pola tanam yang belum terencana dengan baik. Sebaliknya, pada masyarakat perkotaan, diversifikasi terhadap non beras yang berupa gandum lebih disebabkan oleh perubahan gaya hidup, mengingat harga tepung terigu lebih tinggi daripada harga beras untuk menghasilkan nilai kalori yang sama. Padahal produk pangan dalam jumlah memadai dan harga yang terjangkau sangat diperlukan jika mengharapkan orang mengonsumsipangan tersebut.

Media massa juga mempengaruhi sikap masyarakat perkotaan terhadap penerimaan gandum sebagai varian makanan yang dapat diterima. Menurut Cox dan Anderson (Gibney dkk, 2005) pesan yang disampaikan oleh media berpengaruh dalam menentukan permintaan jenis produk pangan tertentu dan pemilihan makanan, setidaknya untuk jangka pendek. Sekarang ini produk olahan gandum berupa biskuit dan roti begitu gencar dipromosikan sehingga sedikit banyak telah menggeser kebiasaan makan nasi di kalangan masyarakat perkotaan.

Masyarakat pedesaan juga merasa bosan mengkonsumsiketela atau jagung, kemungkinan juga disebabkan cara pengolahan yang kurang bervariasi. Sebetulnya terdapat berbagai teknik pengolahan pangan yang bervariasi yang dapat menimbulkan cita rasa yang menyenangkan bagi orang yang mengkonsumsinya, namun hal ini jarang dijumpai pada subjek penelitian. Menurut Gibney dkk (2005) peluang untuk dilakukan diversifikasi makanan sangat besar karena sebetulnya masakan (makanan olahan) jarang bersifat statis. Melalui intervensi berupa perilaku individual dalam bentuk pengolahan makanan dan integrasinya dengan budaya atau teknologi dapat membuat masyarakat mampu menerima makanan tersebut. Bahan pangan pokok seperti singkong (cassava, manioc) yang memiliki permasalahan biologis berupa menimbulkan rasa pahit di lidah dapat diatasi dengan mengolahnya menjadi berbagai jenis masakan yang mampu menghilangkan rasa pahit. Demikian pula jagung yang memiliki kadar protein dan mineral yang rendah dapat diubah menjadi tortilla jagung.

Menurut persepsi penduduk pedesaan, kandungan gizi yang terdapat pada makanan yang dikonsumsi masih kurang, namun sebagian lainnya mengaku bahwa kadar gizinya sudah mencukupi. Jenis makanan yang dikonsumsi sudah bervariasi namun terbatas pada variasi jenis makanan pokoknya, sedangkan variasi makanan tambahan masih minim. Adapun menurut persepsi penduduk perkotaan, kandungan gizi yang terdapat pada makanan yang dikonsumsi sudah cukup memadai, bahkan 
sudah mengandung gizi yang tinggi. Jenis makanan yang dikonsumsi sebagian besar sudah bervariasi. Realitanya, dengan berat yang sama, makanan pokok berbasis terigu menghasilkan kalori tertinggi, disusul makanan berbasis beras, selanjutnya makanan berbasis umbi-umbian, dan makanan berbasis jagung menghasilkan kalori terendah.

Apabila dicermati, harga makanan berbasis terigu paling mahal disusul dengan beras, umbi-umbian dan jagung. Artinya harga makanan pokok berbading lurus dengan kalori yang dihasilkan oleh makanan tersebut, sehingga tidak menjadi masalah secara gizi apabila masyarakat desa yang karena kondisinya membuat mereka menjadikan ketela dan jagung sebagai makanan sehari-hari.

Tingkat pendidikan yang relatif lebih tinggi berpengaruh terhadap pengetahuan tentang diversifikasi pangan pokok. Penduduk pedesaan sebagian besar belum mengetahui program diversifikasi pangan, meskipun sebagian lainnya telah mengetahui program tersebut. Adapun penduduk perkotaan relatif lebih mengetahui pengertian diversifikasi pangan pokok sebagai usaha penganekaragaman jenis bahan pangan dan cara pengolahannya. Meskipun demikian, sebagian kecil subjek memaknai penganekaragaman sebagai usaha mengkonsumsi makanan dengan menu yang seimbang. Temuan ini menunjukkan bahwa pengetahuan mengenai diversifikasi pangan pada masyarakat kota lebih tinggi daripada masyarakat desa. Menurut Firmanzah (2006) masyarakat yang hidup di daerah perkotaan relatif terbiasa mengkonsumsi informasi yang beragam dibandingkan masyarakat yang hidup di pedesaan.

Manfaat utama diversifikasi bagi penduduk pedesaan adalah membantu ketahanan pangan dalam keluarga, terutama karena pangan pokok non beras seperti jagung dan ketela relatif lebih mudah diperoleh, apalagi sebagian besar mata pencaharian subjek penelitian adalah petani yang notabene menanam sendiri ketela dan jagung dimaksud. Bagi subjek penelitian yang pekerjaannya bukan petani, harga ketela dan jagung juga cukup terjangkau dibandingkan harga beras. Adapun subjek perkotaan menilai bahwa manfaat terbanyak dari diversifikasi adalah untuk mencukupi kebutuhan gizi sehingga mempengaruhi tingkat kesehatan dan kecerdasan. Manfaat lainnya adalah sebagai selingan supaya dapat mencoba variasi cita rasa sehingga tidak membosankan dan dapat menambah nafsu makan.

Pangan non beras dapat digunakan sebagai pelengkap dari makanan pokok yang biasa dikonsumsi selama ini. Selain itu pangan non beras dianggap memiliki nilai plus, antara lain harganya yang dianggap murah dan terjangkau oleh masyarakat kecil. Apabila individu menerapkan diversifikasi pangan untuk dirinya maupun keluarganya, diversifikasi tersebut akan memudahkan mereka untuk beradaptasi 
dengan segala situasi, misalnya ketika mereka mengalami kesulitan memperoleh beras, secara fleksibel mereka dapat mengonsumsi pangan pokok lain untuk memenuhi kebutuhan. Kebiasaan melakukan diversifikasi juga secara perlahan akan membuat masyarakat dapat terlepas dari ketergantungan terhadap beras. Sikap masyarakat pedesaan terhadap diversifikasi pangan pokok cukup positif terutama membantu menjaga ketahanan pangan dalam keluarga dan hanya sebagian kecil yang tidak setuju terhadap program diversifikasi. Demikian pula masyarakat perkotaan mayoritas mendukung program diversifikasi pangan pokok dan hanya sebagian kecil yang tidak setuju terhadap program diversifikasi pangan pokok. Temuan tersebut menunjukkan bahwa sebetulnya program diversifikasi pangan ini apabila direncanakan dan diimplementasikan secara serius, makan kemandirian dan ketahanan pangan rakyat Indonesia akan tercapai (Djuwardi, 2010).

Masyarakat pedesaan dalam keseharian sudah menerapkan diversifikasi pangan pokok. Meskipun demikian, kebanyakan mereka mengakui bahwa sebenarnya hal tersebut dilakukan karena tuntutan keadaan. Artinya, tingkat perekonomian yang relatif rendah membuat mereka tidak mampu membeli beras secara rutin. Mata pencaharian sebagai petani atau buruh membuat mereka harus berhemat supaya kebutuhan pangan keluarga tetap terpenuhi, dengan cara mengkonsumsi pangan beras secara berselang-seling dengan pangan pokok non beras. Jadi, apabila dilihat dari kesiapan secara psikologis, sebetulnya masyarakat pedesaan kurang berminat untuk melakukan diversifikasi pangan pokok dan hanya sedikit yang mengkonsumsi pangan non beras berdasarkan minat yang muncul dari dalam diri.

Adapun pada masyarakat perkotaan, banyak yang berminat untuk menerapkan diversifikasi pangan. Meskipun pengetahuan dan sikap terhadap diversifikasi pangan yang dimiliki penduduk perkotaan relatif lebih mendukung, kenyataannya belum banyak masyarakat perkotaan yang menerapkan diversifikasi ini. Meskipun sudah cukup banyak yang menerapkan diversifikasi, sifatnya masih berupa pelengkap atau selingan. Sebagian responden sama sekali belum menerapkan diversifikasi, sedangkan sebagian kecil kadang-kadang sudah berusaha menerapkan diversifikasi pangan terhadap diri dan keluarganya. Ditinjau dari segi kesiapan psikologis, sebagian responden ada yang merasa telah siap namun masih cukup banyak yang merasa belum siap. Sebagian kecil menyatakan siap bila kondisinya memang darurat, semisal krisis beras. Sebagian lagi menyatakan bahwa untuk menerapkan diversifikasi membutuhkan proses adaptasi yang sifatnya bertahap. Temuan ini senada dengan pendapat Gibney dkk (2005) bahwa faktor ekonomi, ketersediaan produk pangan dan faktor psikologi seperti minat sangat mempengaruhi kesiapan dalam pemilihan makanan. 


\section{Simpulan}

Berdasarkan hasil penelitian di atas dapat disimpulkan bahwa : (1) tingkat pengetahuan yang dimiliki tentang diversifikasi pangan pokok pada masyarakat perkotaan lebih tinggi daripada masyarakat pedesaan; (2) masyarakat perkotaan dan pedesaan sama-sama memiliki sikap positif terhadap diversifikasi pangan pokok; (3) masyarakat pedesaan sudah menerapkan diversifikasi pangan pokok, namun motivasinya masih bersifat ekstrinsik; (4) masyarakat perkotaan belum siap menerapkan diversifikasi pangan pokok secara total; (5) terdapat perbedaan jenis pangan pokok non beras yang dipilih antara masyarakat pedesaan dan masyarakat perkotaan. Masyarakat pedesaan memilih ketela (umbi-umbian) sedangkan masyarakat perkotaan memilih makanan olahan berbasis gandum; dan (6) faktorfaktor yang mempengaruhi perbedaan perilaku pemilihan makanan adalah faktor pengetahuan, budaya, akses terhadap produk pangan dan media massa.

Disarankan kepada masyarakat perkotaan untuk belajar menerapkan diversifikasi pangan pokok secara bertahap, karena secara tidak langsung dapat membantu terwujudnya ketahanan pangan. Hal ini dilakukan dengan cara meningkatkan efikasi diri pangan, yaitu kemampuan yang diperoleh untuk melakukan perubahan pola makan. Kepada masyarakat pedesaan, disarankan untuk menambah variasi pengolahan pangan non beras yang selama ini sudah dikonsumsi sehingga tidak timbul kebosanan. Kepada pemerintah Kabupaten Gunungkidul, disarankan untuk menyampaikan sosialisasi pentingnya manfaat diversifikasi kepada masyarakat, sehingga motivasi penerapan diversifikasi yang selama ini sudah dilakukan berubah dari ekstrinsik menjadi intrinsik.

Disarankan pula untuk menggerakkan industri pangan lokal. Caranya dengan memberikan fasilitas kepada usaha menengah dan kecil untuk pengembangan bisnis pangan segar, industri bahan baku, industri pangan olahan dan pangan siap saji. Untuk itu, pemerintah akan melakukan diseminasi paket teknologiterapan, membantu akses permodalan, dan jaringan pemasaran. Kepada pemerintah Kota Yogyakarta, disarankan untuk mensosialisasikan usaha menerapkan diversifikasi secara bertahap kepada masyarakat. Strateginya melalui internalisasi penganekaragaman konsumsi pangan melalui advokasi, kampanye, promosi dan sosialisasi kepada masyarakat umum, pelaku usaha pangan, aparat pusat dan daerah. Selain itu, pendidikan dan penyuluhan melalui jalur pendidikan format dan non-formal bagi siswa SD/MI, kelompok wanita, dan remaja. 


\section{Daftar Pustaka}

Angel, J.F., Blackwell, R.D., dan Miniard., P.W. (1992). Consumer Behavior. Chicago: The Dryden Press.

Anonim. (2006). Pedoman Umum Pengembangan Konsumsi Pangan. www.iptek.apjii.or.id.

Azwar, S. (1988). Sikap Manusia: Teori dan Pengukurannya. Yogyakarta: Liberty.

Bauman. (1996). Sosiologi, Pengertian dan Masalah. Yogyakarta: Kanisius.

Business News. (2010). Dorong Diversifikasi Pangan, 2.000 Desa Jadi Target P2KP. bataviase.co.id/node/390688, diakses tanggal 21 September 2011.

Djuwardi, A. (2010). Cassava: Solusi Membangun Kemandirian Pangan. Jakarta: Grasindo.

Firmanzah. (2006). Antara Pemahaman dan Realitas. Jakarta: Yayasan Obor.

Gibney, M. J., Margetts, B. M., Kearney, J. M., Arab, L. (2005). Gi i Kesehatan Masyarakat. (Terj. Andry Hartono). Jakarta: Penerbit Buku Kedokteran EGC.

LPIST-YASIN. (1992). Panduan Telaah Cepat Situasi bersama Rakyat. Tidak diterbitkan.

Peraturan Pemerintah Republik Indonesia Nomor 68 tahun 2002 tentang Ketahanan Pangan.(2002).

Sarwono, S.W. (1992). Psikologi Lingkungan. Jakarta: Grasindo.

Sears, D.O., Freedman, J.L., dan Peplau, L.A. (1985). Social Psychology. Fifth Edition. Prentice-Hall, Inc.

Soekanto, S. (1998). Sosiologi, Suatu Pengantar Psikologi. Edisi baru keempat. Jakarta: Pegrankindo Persada. 
Subandriyo, T. (2006). Mengukuhkan Kedaulatan Pangan. Suara Merdeka, Sabtu, 16 September 2006.

Suparlan, P. (1995). Kemiskinan di Perkotaan. Jakarta: Yayasan Obor.

Suryabrata, S. (2003). Pengembangan Alat Ukur Psikologis. Yogyakarta: Andi. 